\title{
砂丘の形成と腐植層に関する研究 ${ }^{1)}$
}

\author{
多田交 男2) 長沼信 夫2) ·阿由葉 元 $^{2}$ \\ 角田清 美 ${ }^{2)}$. 市 瀬 由 自 $^{3)}$. 小林和 子 ${ }^{3}$

\section{Research on the Relationship between the Formation of Sand Dunes and Intercalated Humic Layers}

\author{
Fumio Tada, Nobuo Naganuma, Gen Ayuba, Kiyomi Sumita, \\ Yoshimi Ichinose and Kazuko KobAYASHI
}

\begin{abstract}
This paper consists of a historical review on the formation of sand dunes and some considerations on the relationship between the dune formation and the intercalated humus layers in several districts. The following results were obtained;

(1) Buried dunes beneath the surface of Tatebayashi upland in Tochigi Prefecture.

Sand layers constituting the buried dunes are divided in two, both having been deposited under stable circumstances. And volcanic ash layers are found in this district, divided into three; upper, middle and lower. There is every reason to believe that these dunes were formed at the beginning of the fall of the middle ash, or at the end of that of the lower ash.
\end{abstract}

(2) Sand dunes on Sanrihama and Kaetsu uplands.

The formation of some of Sanrihama dunes were due to a relative rising of sea level in early Holocene epoch. At the bottom of shallow valleys in Kaetsu upland, humus accumulation occured in stagnant water prior to the formation of dunes.

(3) Kashima dunes in Ibaragi Prefecture.

In the Kashima peninsula are found sand dunes with three intercalated humus layers, which are thought to have been formed after the formation of sand bars caused by a rise of sea level during the Jōmon culture period, early Holocene.

(4) Genkai dunes in Fukuoka Prefecture.

Sand dunes of this area were formed during the time of high sea level in Pleistocene epoch. Aeolian sand layers are thin in depth and cover uplifted sand bars of marine deposits forming coastal terrace topography. Furthermore, five buried humus layers called Kurosuna are found among sand beds of Holocene dunes, which indicate the ages of dune formation and the stable period.

\section{I.はしがき}

わが国の沿岸には，海岸砂丘が広く分布しており，形 態も複雑で規模も变化に富えでいる。しかしながら，こ れら海岸砂丘の構造, 形成過程および形成時代をみる と, 砂丘の形成環境の類似した時代をいくつか指摘する ことができる. 海岸砂丘の形成時代や固定期をみても, ほぼ類似した時代に行なわれているので, 砂丘の形成や 固定に適した環境が全国的な規模において存在したこと が知られる. 砂丘中の埋没腐植層や砂丘を被覆する腐植 層の存在は, 砂丘形成の休止期や固定期を示すものであ
り, 砂丘の形成と腐植層との関係を知ることは, 腐植層 形成の環境を知るための手がかりをも提供することにな る.

ここでは砂丘の形成に関する研究を辿り，併せて「腐 植土年代学に関する総合的研究」の一環として行なって 来た砂丘の生成と腐植層に関する成果について述べる.

\section{II. 砂丘の形成と腐植層に関する研究史}

わが国における砂丘研究の歴史の中で, 昭和 15 年, 16 年に行なわれた多田, 保柳, 大塚らによる内蒙古渾善 克達砂漠地带の研究は大きな成果をもたらした（多田：

1) 1971 年 8 月 19 日 受付

2) 駒沢大学交学部地理学教室, Department of Geography, Faculty of Literature, Komazawa University

3) 法政大学交学部地理学教室, Department of Geography, Faculty of Literature, Hōsei University 
1946). それは（i）渾善達克砂漠地带では, バルハン 型の堆積砂丘に対して，草によって密に蔽われ，かつ， 風上側の西向きに凹陥地をもったマン八型の侵食砂丘の 拡がりの広いこと.および (ii) マン八型砂丘の西側斜 面に穿たれ凹陥地の東側壁を作る急崖をみると，かつて 形成された固定砂丘の地表面を示す黒色砂層があり，こ の黑色砂層を境としてマン八型砂丘は下部の埋積された 古砂丘と上部の新砂丘とに分けられることであった。 こ の研究が契機となって，わが国の砂丘の中にも同じよう に複雑な形成過程を辿った砂丘があることが判ってき た。

（1）ローム層下の埋積砂丘 その結果として関東地 方でローム層下に埋積された砂丘のあることが発見され た、利根川中流の館林台地上には利根川畔の古海から天 神原を経て多多良湖畔の高根に至るまで延長 $6 \mathrm{~km} \mathrm{に及}$ んで数列の丘があり，その高さは台地より $10 \mathrm{~m}$ 高く幅 は $200 \mathrm{~m}$ ばかりである. 多田 (1947) はこの砂丘状の地 形が列状に配列していて, 現在幸手付近にみられる数列 の自然堤防およびその上の河畔砂丘と形が似ていて, 位 置も近いことから，この高まりを.河畔砂丘と考えてお り, 当時の利根川の河況方幸手付近における古利根川流 域のそれに似ていたことを示すものと考えた．館林台 地上の高をりを作る地質は砂之細かい火山浮石の互層か らなり, 数 $\mathrm{m}$ の厚さの関東ロームにおおわれているの で，これらの高亡りの成因をローム層によっておおわれ 埋積砂丘となったものと考光た。

貝塚（1958）は砂丘をお打うローム層は上部および中 部ローム層であり, 砂丘列のもっとも西側のものは下部 ローム層におおわれるのではないかと述べている。ま た，同様なローム層におおわれた砂丘よりなる高まり は, 原町田の南方 $3 \mathrm{~km}$ 付近の江, 島線中央林間駅付近 においても知られている。多田 (1947) はこの砂よりな る高まりも館林台地のそれと同じものではないかと考元 たが，戸谷（1960）はこれらの高まりの成因について河 畔砂丘的なものと考えるの注その方向から言って無理で あろうと述べている. そして背後に平行して続く凹地と の関係から,むしろ扇状三角州上の旧海岸線に関連した beach ridge と言った方が可能性が強いと考えている.

その頃, 多田 (1946) は鳥取砂丘の研究を行ない, ス リバチの凹地底に火山灰層らしきものを発見して，鳥取 砂丘はこの火山在層によって古砂丘と新砂丘に分けられ ることを述べた．さらに昭和 23 年には小笠原 (1948) は, 鳥取砂丘の古砂丘は火山灰層によって埋積された 砂丘であることを発表した。この時共同調查を行なった

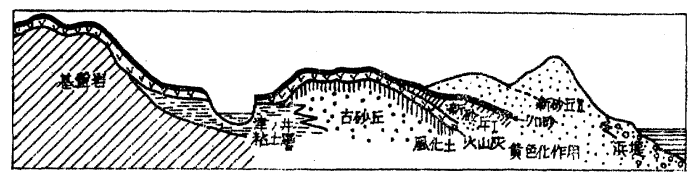

第 1 図鳥取砂丘の概念図（豊島・赤木(1965) による)

大西 (1961) はその後も研究を続けて火山兏層は大山火 山に由来するものであることを指摘した。

昭和 40 年には豊島: 赤木 (1965) によって鳥取砂丘 においても腐植を含む黒色砂層分発見され，黒色砂層を 境として新砂丘が新砂丘 I, 新砂丘I に分けられるよう になった・第 1 図は画氏によって描かれた鳥取砂丘の概 念図である，基盤山地の山麓には津ノ井粘土層よりなる 比高数mの津ノ井面 (堆積面) がある.これより海岸側 には古砂丘が堆積しているが，津ノ井面や古砂丘上には 火山灰層やク口砂がのるので，津ノ井粘土層や古砂丘砂 層は同時異層と夕ることが出来る. 古砂丘の海岸寄には 新砂丘 I 上にク口砂層がのる. 新砂丘I の堆積物は何 れも黄色化作用を受けて風化が進み，かなり固化してい て, クロ砂層の上にのる新砂丘】堆積物とは異なって いる. ク口砂層の中からは古墳時代末期までの遺物が出 土することが知られており, 新砂丘 II は移動砂丘の堆積 速度の実験結果より, 紀元 700〜800 年以降に堆積した ものであると推定されている.

（2）黑色砂層下の埋積砂丘 ロ-ム層下の埋積砂丘 の研究とともに, 黒色砂層によって化石された埋積砂丘 の研究も行なわれた. その最初の成果は川田三郎(1946) によって確認された河北潟砂丘中の埋没腐植層である. 河北潟砂丘は砂丘中に含まれる黒褐色腐植層によって形 成時期を異にする新旧二期の砂丘に分けられ，下部の成 層する砂丘砂の堆積後, 無層理の砂層が堆積するような 環境があり，その後無層理の砂丘上に針葉樹が繁茂して 砂丘は固定され，黑褐色腐植層が砂丘表面に形成され た.しかし，この時期は余り長く継続されず，腐植層を おおって新期砂丘層が堆積したために，旧期の砂丘は埋 積砂丘となったと述べている. その後, 北陸地方のこの 地帯にみられる黒褐色腐植層の最上部には, 繩文中期〜 弥生後期, または古墤時代初期の土器と石器が包含され ることが報告され，黒褐色腐植層の形成時代を推定する ことが可能になった.

なお，藤 則雄 (1966) は北陸地方の海岸砂丘を広く 調査して，この地方の沖積世地史をつぎのように編えで いる.

沖積世の最大海進期の汀線は，射水平野では現海抜 4 
$\mathrm{m}$ のところ, 河北潟周辺では海抜 $5 \mathrm{~m}$ のところにあっ た. この大海進後の海水面の急速な低下によって海進時 の砂州であった部分が砂丘となった．これが河北潟の北 西側にある内灘地方の黑色泥炭質砂の下位にある古砂丘 である.この砂丘の発達によってそれまで入江であった 内陸部が潟湖となった．放生潟，河北潟などは何れるこ の時期に潟湖となったものである. 繩文中頃になると， 気候がやや冷涼化したために海水面が低下して現水深 0 ないし $5 \mathrm{~m}$ の現海底は海岸低地となり，そこに森林が繁 茂した. 有名な魚津の埋没林はこの時期の代表的な森林 である. 当時の汀線は現在の汀線よりも $500 \mathrm{~m}$ も沖合に あった．このために当時は内灘砂丘（河北潟砂丘）まで は砂は飛えでこなくなって古砂丘の表面には草が生え， それが枯れて腐植となり，表面の砂を黑色に染めた．こ の表面が繩文中期から弥生後期または古墳時代初期まで の人々の生活の舞台となったのである. その後弥生時代 から古墳時代にかけて気候が少しく温暖化し海水面が上

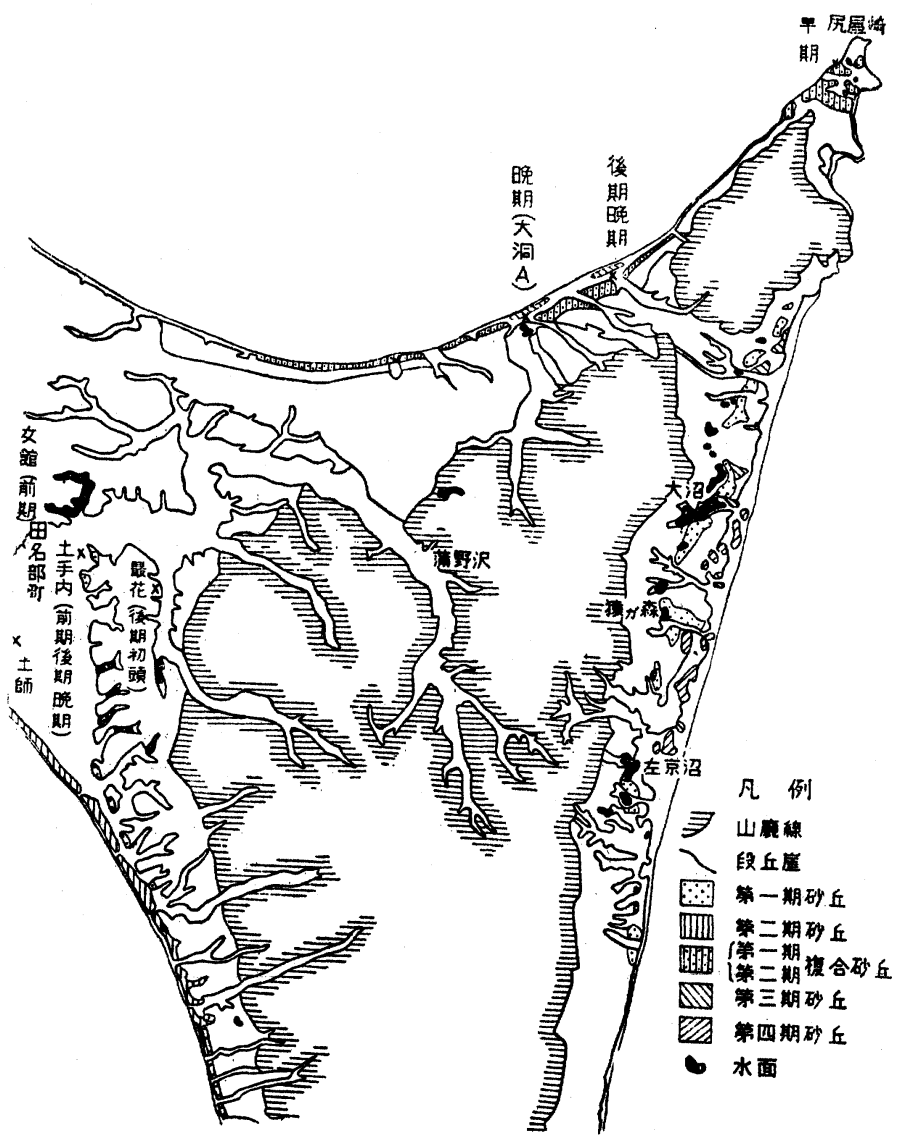

第 2 図下北半島砂丘分布図
昇したこのためにそれまで現在の沖にあった汀線が急 速に内陸侵入して来て，かつての汀線付近に繁ってい た森林は海面下に没して魚津にみるような埋没林となっ た、海の近くになった内灘の古砂丘上にも，新期に砂が 供給されるようになり新砂丘が形成された．入江状の潟 は新砂丘の形成によって完全に閉寒されてしまった，現 在の汀線付近にある渴湖はこのようにして形成された。

また同じころ小笠原（1946）によって荘内砂丘の研究 が行なわれ，ここでも砂斥中に黑色砂層の存在が確認さ れた，黑色砂層の大部分は泥および腐植質からなり，黑 色砂層を境として下部の古砂丘と上部の新砂丘よりなる ことが知られた，古砂丘の形式期には冬の季節風が著し く，最上川の河口からは多量の土砂が供給されたが，そ の後気候が湿潤化して表面に腐植層が集積するようにな り，黑色砂層が形成された，黑色砂層の堆積によって固 定された古砂丘には再び砂層が供給されて新砂丘を形成 したが，その時期は赤川新川切割の泥炭層上の砂丘表面

下 $30 \mathrm{~m}$ のところに土器が発見され るからきわめて新しい時代の出来ご とであると指摘している．小笠原の 研究の後に, 古砂丘最上部の腐植質 砂層中に含まれる炭質物を用いて ${ }^{14} \mathrm{C}$ による絶対年代の測定が行なわ

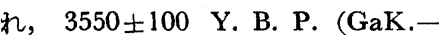
1235）という結果が得られている （東北農政局計画部，1968)。また， 新砂丘の形成が繩文後期〜睌期以降 に行なわれていることが判明し（東 北農政局計画部，1968），荘内 砂丘 中の古砂丘の形成は $3550 \pm 100 \mathrm{Y}$. B.P.またはそれ以前であることが 知られるようになった。

（3）三列の砂制と砂丘市瀬 (1962) は下北半島, 南九州志布志湾 沿岸，弓ケ浜半島において砂丘を調 査し，それらが（i） 3 列の砂州と 砂丘からなること． (ii) もっとも 古い時代に形成された第 I 列砂州, 砂丘列が内陸側にあって第 I 列, 第 I列と新しいものほど現汀線に近く 存在することなどを明らかにした。 これはわが国全般に共通した特性で あり，生成時期もほぼ同じ時代であ ると考えられる. 弓ケ浜半島では先 
史時代の遺跡, 遺物に関する資料が少なく, 形成時期を 決定することが出来なかったが，下北半島では第 I 列砂 州, 砂丘(第 I 期砂丘) は繩文早期の後半ごろまたはそれ 以前に (第 2 図)，志布志湾沿岸では繩文後期ごるまた はそれ以前である. そしてこれらは沖積世初期の海水準 が相対的に高い位置に置かれていた時代に形成されたも のであることを明らかにした。

第 I 列砂州の上に砂丘が形成されているが，その砂丘 は下北半島では形成後に腐植層によって, 志布志湾沿岸 では腐植交り黑色火山灰層によって固定されたこれら の砂丘は固定された後に風蝕を受けて凹地を形成し，侵 食砂丘となっている. ヨケ浜半島でも第 I 列砂州上に形 成されている砂丘は侵食砂丘となっており，鹿島半島の 内陸にある八光台砂丘の侵蝕砂丘とも似ている．第列 砂州とその上にのる砂丘は，弓ケ浜半島では第 I 列砂州 砂丘の前面にあって半島中央部に帯状に拡がっている. 下北半島でもこの時期に対比される砂丘の形成時代は続 繩文〜土阶の時代であり，志布志湾沿岸では繩交後期以 降一 5 世紀後半〜 6 世紀（横瀬古墳）の間である.この 時代には雨地域とも海面は現在よりも若干高い位置にあ ったが，既に現在の平野と大差のない地形が形成されて

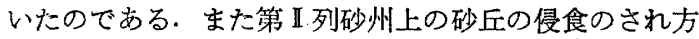
は第 I 列砂州上のそれよりは少なくなっている.

第吕列砂州およびその上にのる砂丘はもっとも外側に あり，下北半島では土師以降のある時代である．志布志 湾沿岸では表面に火山灰層も㩦植層もみられなく, 第 $\mathbb{I}$ 列砂州砂丘を蔽っていたり，あるいはそれらの前面に位 置することなどから，土師以後と推定される．弓ケ浜半 島でも歴史時代に形成されたものである.わが国の海岸 砂丘の形成をみると，2３回にわたる形成時代があり，
またその間に 2 回ぐらいの海岸砂丘の固定された時代が あって，海水準の 変化との関係が指摘され，三列の砂 州の形成された当時の汀線はだんだんと低くなり，その 間の時期に汀線の高い時期がはさまれたと考えられる. 三位 (1966) は八郎潟その他の日本海岸で砂州が最大 3 列あり，内陸から海岸に向って断続的な前進があったこ とを明らかにしている。また，三位は沖積世大海進後に おける内外の旧汀線堆積物の ${ }^{14} \mathrm{C}$ 年と埋没深度ないし標 高との関係を図示して, 世界の汀線高度に 3 回の高低時 代があり，これと砂州，砂丘の形成と深い関係にあるこ とを論じている. すなわち, 温暖な海面の高かった時代 に砂州や砂丘が形成され，ついできた冷涼な海面の低か った時代に砂丘の侵食が行なわれたことが推定できるの である。

\section{III. 砂丘の形成と腐植首に関する研究}

われわれは上述した研究の上に立って，「腐植土年代 学に関する総合的研究」の一環として, 砂丘の形成と腐 植層に関する研究を行なって来たので，つぎにその成果 について述べる. 対象とした砂丘は 館林台地の埋積砂 丘, 三里浜 ·加越台地上の砂丘, 鹿島砂丘, 玄海砂丘な どである。

（1）館林台地の埋樻砂丘と腐植層 館林台地の西部 には利根川の旧流路と思われる帯状の凹地が古海から多 々良方面に続いており，その東および南縁の台地上には ロ一ム層におお小れた埋積砂丘列が分布する．これらの 埋積砂丘の中には，並びかたがやや南西から北東方向に 向う小規模な砂丘列がみられる.これは比高 $2 \mathrm{~m}$ 内外の ローム層におおわれた高まりで，やはり台地上に位置し ている．この高まりを示す列は自然堤防をかたちづくる

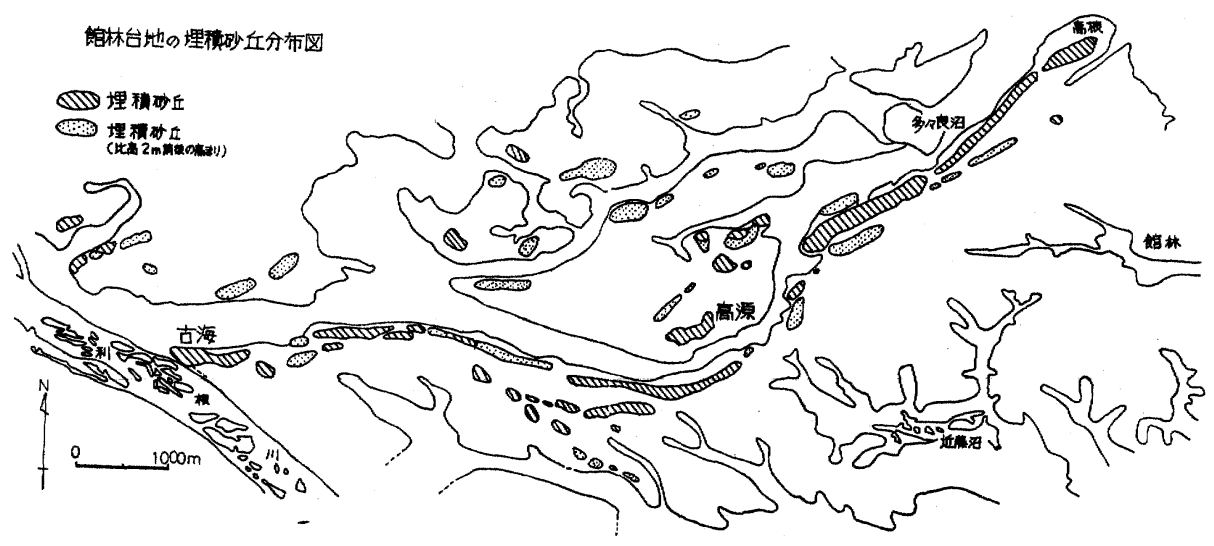

第 3 図館林台地の埋積砂丘分布図 


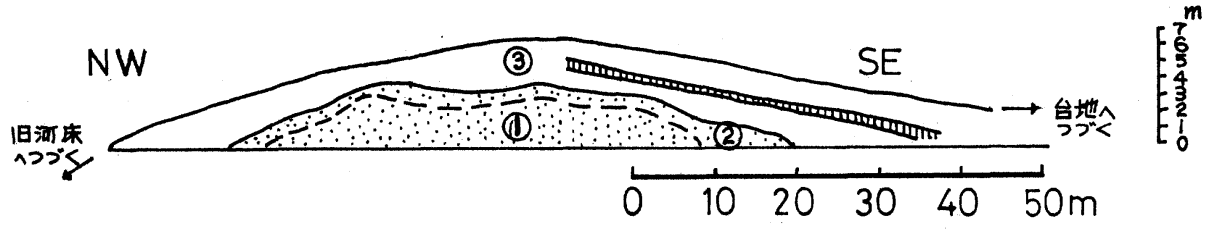

第.4図 埋積砂丘横断面図（高根）

ものか，あるいは砂丘をかたちづくるものなのか現在の 段階では明らかでないが，第 3 図には分布形態などから 埋積砂丘として示してある。

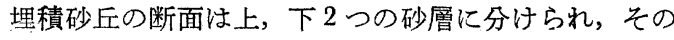
上にローム層が堆積している（第 4 困）．下部の砂層 （1)）は，全般的に肌色を呈し，砂，シルト，ローム， 軽石が混り合ってラミナ状に堆積している，上部の砂層 は全般的に青灰色を呈し，砂，シルト，それに軽石が混 り合い，下部の砂層をおおうような形でラミナ状をなし て下部の砂層の上に厚さ $50 \mathrm{~cm} \pm$ で堆積している.なお これら上部，下部の砂層は約 $30^{\circ}$ の傾斜をもって凹地に のぞんでいる.

砂層は上部，下部の 2 層に区分したが，その境界は必 ずしも明瞭ではなく，ただ砂層の色の違いやロームの多 少によって区別している．この砂層の粒度分析の結果を みても，下部の砂層は $60 \%$ 以上が粒径 $0.5 \sim 0.25 \mathrm{~mm}$, 約 $15 \%$ が粒径 $0.25 \mathrm{~mm}$ 以下，上部の砂層は約 $60 \%$ が 粒径 $0.5 \sim 0.25 \mathrm{~mm}$, 約 $20 \%$ が粒径 $0.25 \mathrm{~mm}$ 以下で あって，上部，下部の砂層とも粒度組成の差はほとんど みられない，ただ下部砂層は砂とシルト質ロームの互層 よりなる層理が顕著に発達しており, 部分的にシルト質 ロームの含有の差により細粒砂，粗粒砂がみられる．こ のように砂が細粒で均一であることから，砂層の下部か ら上部まで安定した環境の下で堆積したとみられる。こ のことは埋積砂丘の中に顕著な腐植層を含えでいないこ とによっても裏付けられる.ただ下部の肌色砂層と上部 の青灰色砂層との色調の差池下水の影響を受けたため の溶脱，集積の差によるものと考えられる.

これら砂層の上には中部ローム（皁武蔵野ロームに 相当)，上部ローム（ほぼ立川ロームに相当）が約 $2 \mathrm{~m}$ の厚さで堆積している，このローム層中には，ほぼ上部 ローム層の直下に腐植を挾えでいる，腐植層は風下側に 顕著にみられ，風上側には発達がわるい，この腐植層の 発達のちがいはどのような形成環境のもとで生じたの か，また卓越風の影響を少なからず受けていたのかなど は不明であるので, 今後の研究課題としたい.

なお，砂丘の形成時代については，館林台地上に堆積
した埋積砂丘は，（1）上部ローム層掞よび中部ローム層 におおわれること，（2）上部の砂丘にはローム層はみ られなく軽石のみを含むこと，（3）下部の砂層は全般 的にロームと砂の互層の多いことから，この砂丘砂の堆 積した時期にはロームの供給が多かったこと，などを併 せ考えると，砂丘砂層中の軽石およびシルト質ローム層 は中部口ーム層降灰の初期か，あるいは下部口ーム層 降灰の末期ではないかと考えられる。このことは貝塚 (1958) が指摘しているように，館林台地西部には下部 ローム層の堆積がみられることからも推察できるのであ る.

（2）三里浜・加越台地上の砂丘亡腐植層 九頭竜川 河口にある三里浜砂丘および福井平野のボーリング資料 をみると, 砂丘砂層の下部には粘土層, 粘土混り砂層お よび細砂層などの細粒物質が堆積し，その下部には局地 的に大粒な砂利を含む砂れき層があり，この細粒埋積物 は上部粘土層と名づけられる.この上部粘土層は層相, 層位および地形との関係などからみて沖積世の海進時の 堆積物であり, 内陸側の砂丘列 (山岸 - 黒目 ·米納津 · 白方を連ねるもの）は沖積世の海水準の相対的上昇時に 形成された砂丘である. 福井平野では地形や表層の構成 物質よりみて，ほ漂高 $5 \mathrm{~m}$ 以下の三角州は繩交時代の 海によっておおわれた地域とみられるが，砂丘形成との 関係については考古学的資料が少なく, 詳しく知ること は出来ないので今後の研究課題としたい，また，沖積砂 丘中の埋没腐植層については確認することが出来なかっ た。

なお，三里浜砂丘の北部に連なる加越台地の一部には 海食崖上に砂丘砂が這い上って海岸砂丘（侵食砂丘）を 形成し，その砂丘の直下に横たわるローム層の上部に局 部的に腐植層がみられるので，この腐植層の生成環境に ついて考察した.

大聖寺川の河口にある見当山南西方 $1 \mathrm{~km}$ 付近の海食 崖 (Loc. 13) をみると（第 5 困), 砂丘砂とローム層と の間には腐植層が局地的に発達する。しかも腐植層は浅 い凹地形を埋めて発達し, 凹地形の周辺には腐植層は薄 くなるかまたは発達しない。また，腐植層（30～ $55 \mathrm{~cm})$ 


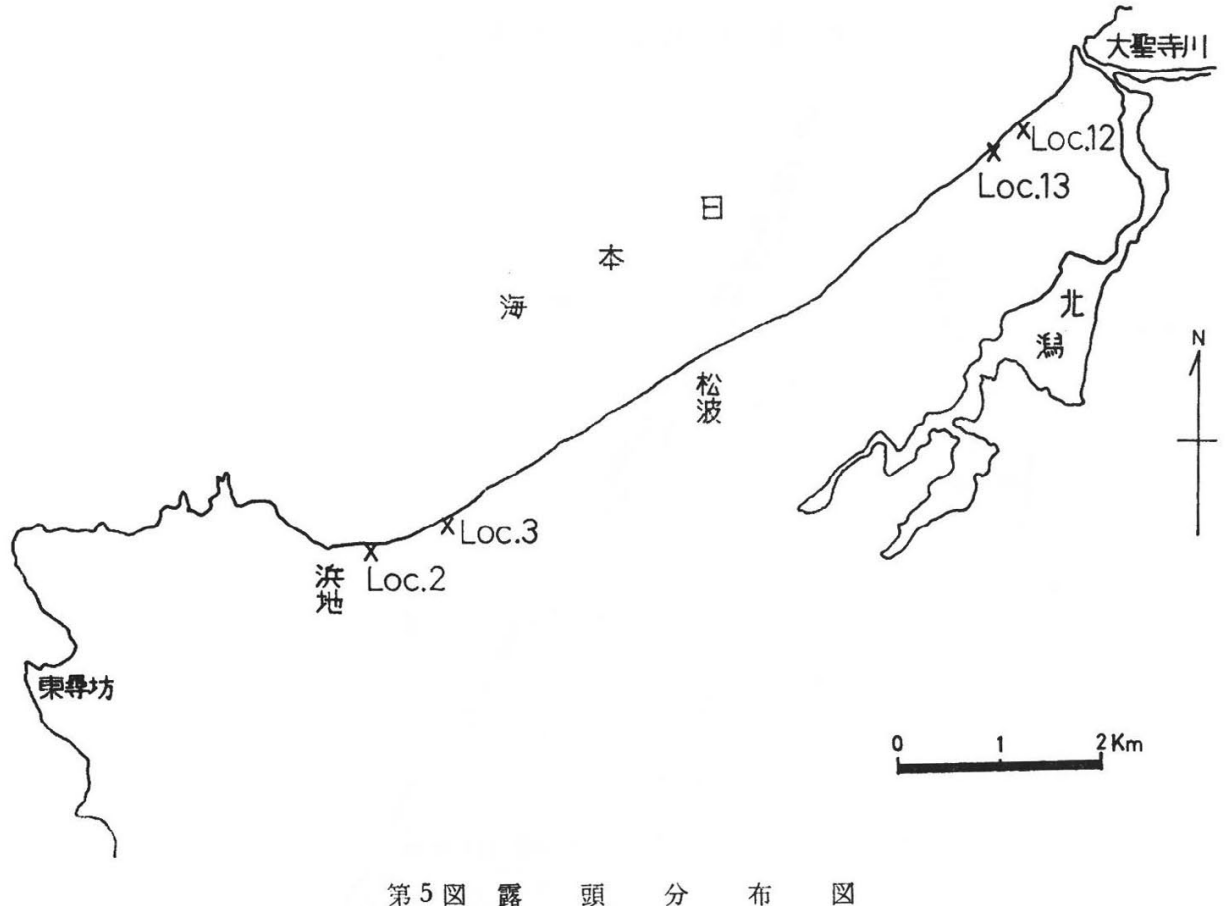

の下部には樹皮などを含む下部泥炭層 (厚さ最大 $25 \mathrm{~cm}$ ) がある.この泥炭層は凹地形でもみられなくなるところ があり，腐植層が直接下部の青灰白色のローム混り砂層 上にのることもある. この腐植層の上部にも厚さ $0 \sim 25$ $\mathrm{cm}$ の上部泥炭層がのり，拡がりは下部の泥炭層よりも 広くなるが，凹地形に接する台地面では泥炭層は薄失し て火山灰層が現われ，その上に腐植層がのる．下部の泥 炭層の下には青灰白色の堅いローム混り砂層（厚さ70 $\mathrm{cm})$ があり，上部より $20 \mathrm{~cm}$ はローム它含み粘土化す るが，下部泥炭層との境界は明瞭である．この下には青 灰色の粘土層 (厚さ $1 \sim 3 \mathrm{~cm}$ ) と砂層 (厚さ $4 \sim 10 \mathrm{~cm}$ ) との互層（約 $80 \mathrm{~cm}$ ）があり，下位の青灰色の凝灰質砂 質粘土層（厚さ $25 \mathrm{~cm}$ ) に続く. Loc. 13 ではこれらの 粘土層や砂質粘土層が凹地形における停滞水の存在を可 能にしたものであろう.

Loc. 3 でもロームにおおわれた浅い凹地を埋めて腐 植層（最大 $55 \mathrm{~cm}$ ）がみられ，その下部に腐植混りのロ 一ム層 (厚さ $10 \mathrm{~cm}$ ), さらに下部は厚さ $1 \mathrm{~m}$ の青灰色 のローム層に移るが，腐植混りのローム層との境は明瞭 である. Loc. 13 においては泥炭層の基底に青灰白色の ローム混り砂層（上部の $20 \mathrm{~cm}$ はロームを含み粘土化す る）が現われたり，Loc. 3 においては腐植混りのロー ム層の下部に青灰色のローム層が現われることは, 浅い
凹地形とも併せ考えると，ローム層の一部は水成堆積相 を示してグライ化作用を受けているのではないかと考え られる。

また，Loc. 12 ではローム層（厚さ $70 \mathrm{~cm} \sim 100 \mathrm{~cm}$ ) を切って形成された谷を埋めて植腐層が発達する.ここ では砂丘層の下に第 1 層は植物の遺体などを含まない厚 さ最大 $45 \mathrm{~cm}$ の腐植層で，上部には局部的に褐鉄鉱の殼 がみられる。

第 2 層は厚さ最大 $35 \sim 40 \mathrm{~cm}$ の灰色を帯びた暗褐色 の腐植層よりなり，一部に湿地性植物の遺体を含えでい

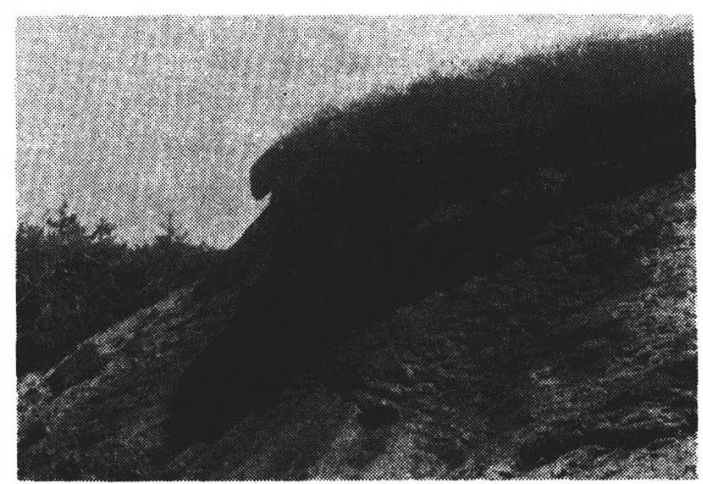

写真 1 ローム台地上の浅い凹地形を埋めて発達する腐 植層 
Fig. 1 鹿島羊島砂丘分布园

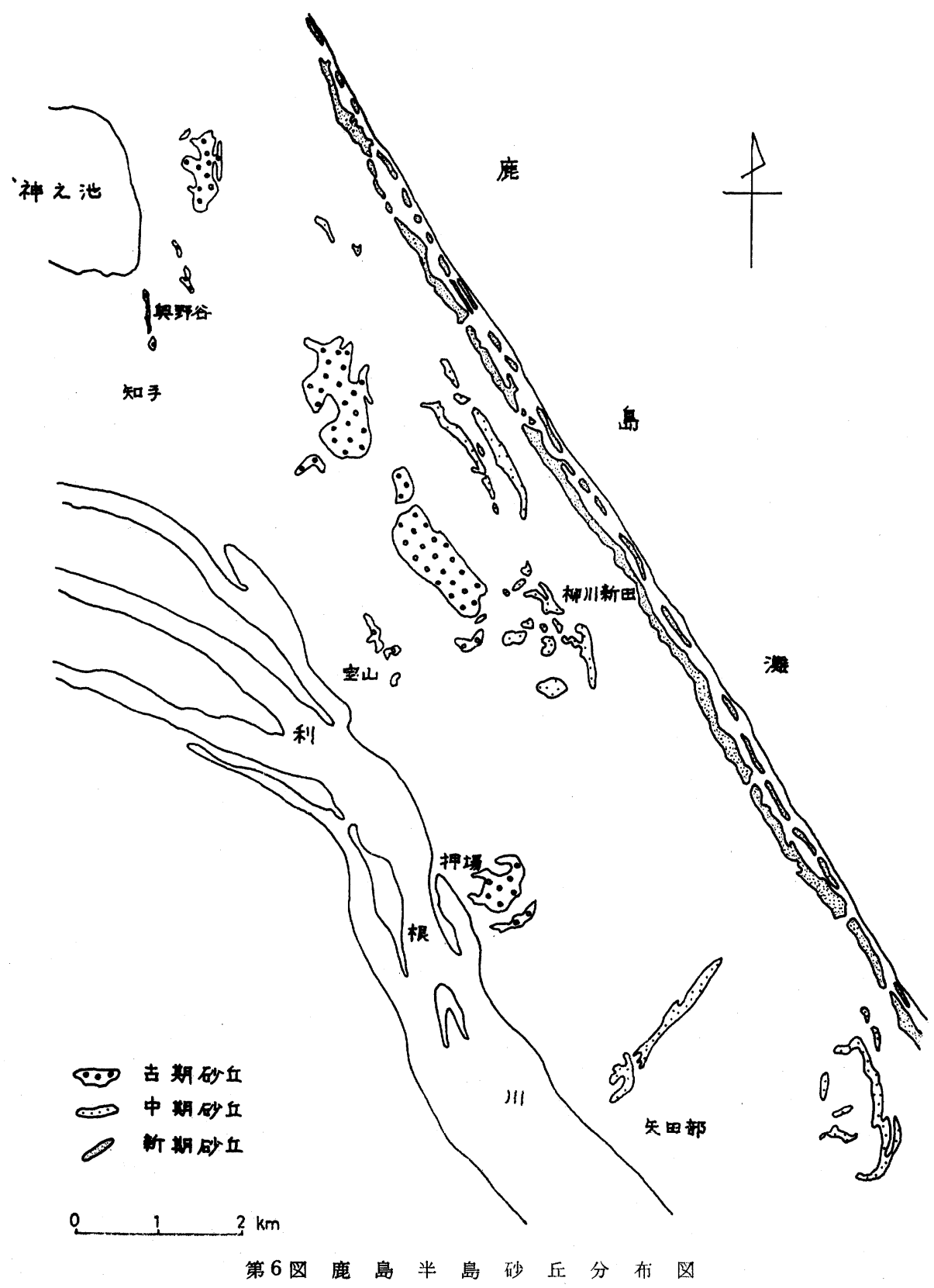

る. その下位の 第 3 層は褐色の強い腐植層（厚さ最大 下の凹地の底部では褐灰色の砂混り口ーム層（厚さ10 $10 \mathrm{~cm}$ ) で，下部には褐鉄鉱が集積して盤層（厚さ $5 \mathrm{~cm} \quad \mathrm{~cm}$ ) を経て風成のローム層に続いている. Loc. 12 では 土）を形成する. 第 4 層は厚さ最大 $70 \mathrm{~cm}$ の腐植層で, 第 4 層, 第 3 層, 第 2 層までは凹地形の中に, 第 1 層は 下部 $20 \mathrm{~cm}$ はやや褐色を帯びて堅くしまっている，その回地形を埋めて周辺にまで拡がるが，微高部では薄失す 
る（军真 1).な技，Loc. 2 でもロームを切った谷を埋 める腐植層（厚さ $150 \mathrm{~cm}$ ) をみることができる，付近 の台地上の應植層の厚さは 40 ～ $60 \mathrm{~cm}$ である.

これらの露頭におけるロ一ム層やその下位の粘土層お よび腐植層の産状から，ローム層の一部が凹地形に堆積 してグライ化作用を受けたり，泥炭層の形成と結びつい て腐植が集積していることは，崖端付近の砂丘形成前に 凹地形では停滞水のみられる環境下において腐植の集積 が行なわれたものと考えられる。なお，Loc. 13 の下部 泥炭層の年代測定の結果は $13,110 \pm 340$ Y. B. P. (Gak. -2848) であった. Loc. 13 付近の凹地形ではこの頃か ら泥炭層の形成が始まり，続いて低湿な環境の下で腐植 層の集積が行なわれたものと推定される．また，この腐 植層をおおう海食崖上の海岸砂丘（風食を受け侵食砂丘 となっている）の形成時代の下限をも垪せて知ることが できる.

（3）鹿島砂丘における埋没腐植屬 鹿島砂丘の生成 環境と埋没腐植層の関係を知るために考察を行なった。 その結果, 奥野谷から波崎に至る砂丘は形成年代に上。 て古期砂丘，中期砂丘，新期腐丘に分類される．分布は 第 6 図に示す.

(i) 古期砂丘

古期砂丘は標高 39 20m である. 分布は押場より北 部に限られ，半島ののびの方向 (NW 方向) に一致す る. 古期砂丘砂層の砂鉄層理から知りえた砂丘の走向も NWをとるものが多い. 粒径は 70\%が $\phi 2 \sim \phi 3$ に集 中する. 茨城県・建設省 (1964) によれば，鹿島半島の 上部砂れき層 (U.S.) は凹凸が大きく，砂州状になって いるという. 菊地隆男 (1968) は約 6000 年前の海進時 に砂州が形成されたとしている．このような砂州を基盤 として古期砂丘が形成されたと考える. 西宝山ないし押 場では砂れき層直上に $20 \mathrm{~cm}$ あまりのきわめて連続性の よい腐植層を挾み，その上に古期砂丘砂をのせている。 この腐植層は東京農工大学黑部研究室の分析によれば, 後述の 2 腐植層にくらべて 腐植酸の量が大であるとい う. この腐植酸の年代測定の結果, $1950 \pm 150$ Y. B. P. （Gak.-3331）の值が得られた. 従って西宝山ないし押 場ではこれより新しく古期砂丘が形成されたことにな る.

奥野谷において和島ら (1968) は「奥野谷貝埭は砂州 上の $6 \mathrm{~m}$ 砂丘の上にのっていて，それは繩文前期末〜中 期初頭の土器を含み，陸上に積成されたものである.」 と述へててる. 従って西宝山ないし押場の砂丘と, 奥野 谷の砂丘との間には明らかに時代のつれがある. 奥野
谷, 八光台と知手の東側の大きな砂丘については，砂れ き層と腐植層の関係が確認出来ていない. 従って, これ がわかればさらに古いものとして細分される可能性があ るが，不明のため一括して古期砂丘とした. 古期砂丘 は多田 (1943，1948）によってマン八型砂丘であると報 告された.この風食の開始の時代は腐植層との関係がつ かめず不明である.

(ii) 中期砂丘

中期砂丘は標高 10〜 15m で, 古期砂丘の南東側に 接して 現海岸の位置に支配された形で北西側にのび る. 両宝山付近では中期砂丘の下限と, 新期砂丘の下限 近くにそれぞれ一枚の腐植層を挾む。後者はきわめて連 続性が悪い。この 2 枚は前述した腐植層に比較して腐植 酸が少なく，ほとえどフルボ酸からなる（両者は年代測 定依頼中). 中期砂丘砂層の走向はほとえどの場合 $\mathrm{NE}$ 方向である・柳川新田では中期砂丘下に埋没している古 期砂丘砂層の走向は NW 方向であり，中期砂層と明ら かに走向を異にしている. 古期砂丘形成期と中期砂丘形 成期には腐植層が発達するような環境下にあり，明瞭な 間げきが存在した。ささらに両砂丘の形成において，飛砂 の方向, ひいては砂の供給位置にらがいがあったようで ある.中期砂丘もマン八型砂丘であり，最上部の新期砂 層をきって凹地が存在することから, 新期砂層堆積後, 凹地侵食が行なわれたと考える.

(iii) 新期砂丘

海岸に平行に分布する 2 ないし 3 列の砂丘で, 標高は $10 \mathrm{~m}$ 以下である. 近年人為的に形成された砂丘をも含 む.この砂丘は砂鉄の層埋が明膫に発達していないとと が多く，砂層の走向は測定できない。また腐植層はみら れない, 砂粒は古期, 中期砂丘にくらべて非常にあらく $50 \%$ が $\phi 1 \sim \phi 2$ に集中する.

これらの砂丘を模式断面として第7図に示した. 鹿島 半島においては繩交海進による砂州形成後, 三回の腐植 層形成期をはさみ，砂丘が形成された，この腐植層の発 達は古気候变化よりもむしろ, 砂丘形成途中の急激な環 境変化にともなう砂の供給の中断が大きな要因になって いるためではないかと考える.

（4）玄海砂丘の黒砂層 玄海砂丘は海岸に沿って発 達し, 最高高度は約 $52 \mathrm{~m}$ である. 遠賀川河口右岸（若 松半島）の発達は悪い。河口左岸には砂丘の主部があ り, 砂丘地は東西約 $10 \mathrm{~km}$, 南北約 $3 \mathrm{~km}$ である. 左岸 の砂丘地は起伏, 高度, 形態, 連続性, 構成物質および 形成時代などによって㹃屋砂丘, 芦屋砂丘, 三里松原砂 丘に区分することが出来る（第 8 困). 


\section{古期 砂 丘中期砂丘新期砂丘}

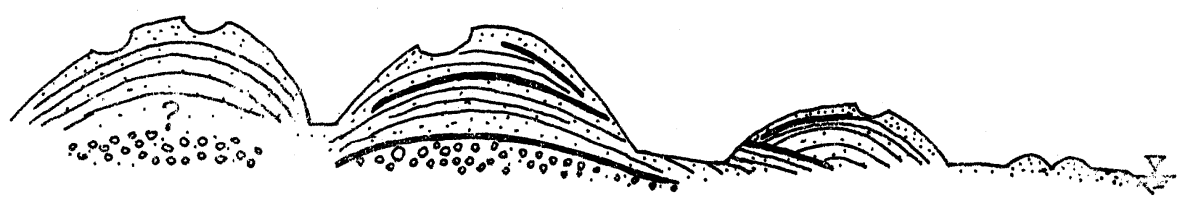

\section{席植壁} $\because 00 \%$ 砂地

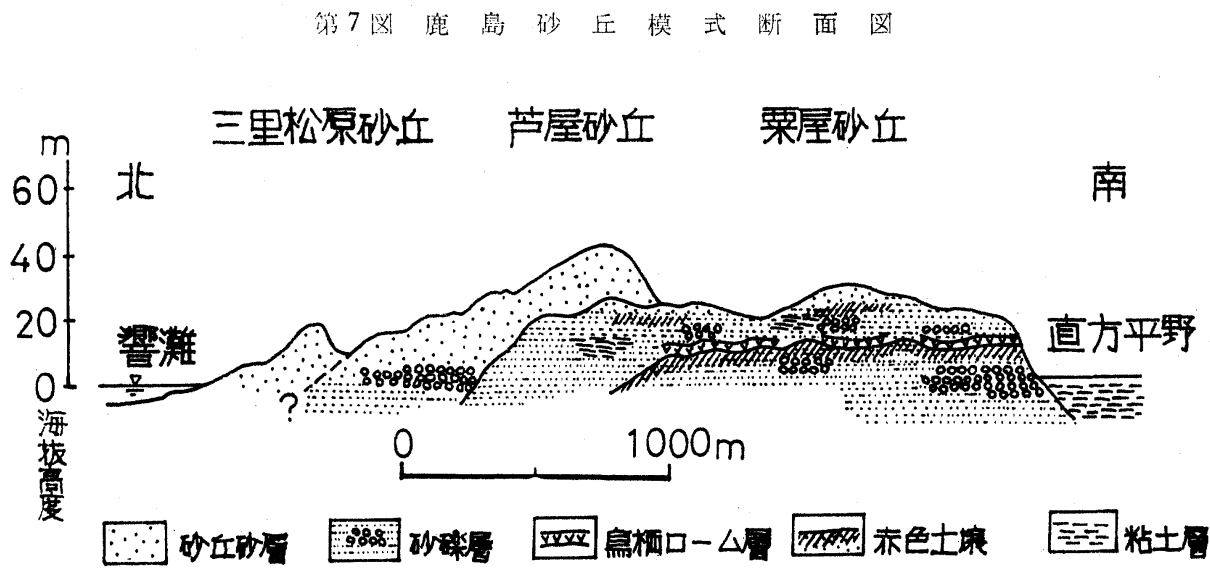

第 8 因玄海 砂 丘 9 概 念 図

\section{(i) 粡屋砂丘}

表面の起伏はゆるやかで 20～30m の面が広く，その 面上には比高 5〜10m の小丘がいくつか分布している. 小丘は風成砂よりなる砂丘であるが，20～30m の面は 水中堆積の砂層, 砂れき層よりなり,鳥栖ローム層（新期 阿蘇熔岩の未端相）によって下位の鬼津砂れき層と上位 の大城砂層に分けることが出来る．鬼津砂れき層と鳥 栖口一ム層は不整合関係で，不整合面は赤褐色（5 YR $4 / 8)$ ～明赤褐色 (2.5 YR 5/6) を示し，赤色土壤化作 用を受けた古土壤である。鳥栖口ーム層の層厚は場所に より異なりもっとも厚いところでは $150 \mathrm{~cm}$ 以上を示 すが，わずかに上位の大城砂層基底部に軽石塊としてみ られる場所もある.大城砂層は一部で鬼津砂れき層や鳥 栖口ーム層を切って不整合にのる. これらの堆積面上に 風成砂層（黒山砂層）がのり，砂丘を形成する. 大城砂 層と黑山砂層は漸移し, 赤色土壤化作用を受けている.

(ii) 芦屋砂丘

この砂丘は琻屋砂丘の上にクロスナを挾えだ田屋砂層 がのってできた砂丘である、 (iii) 三里松原砂丘

これは海岸に沿って分布するもっとも新しい砂丘で， 芦屋砂丘とは地形の不連続をもって接する，表面の起伏 が複雑でその一部は形成時代を示すと思われるが不明で ある．この砂丘は田屋砂層（風成砂層）よりなり，砂層 内にはクロスナ層が㣣まれ，砂層内に含まれる人類遺物 や ${ }^{14} \mathrm{C}$ 年代測定によって時代を決めることが出来る. 最 下位のクロスナ層には繩文早期〜前期頃の細隆線交土器 が含まれ，その上位のクロスナ層には繩文中期末から繩 交後期中葉の磨耗繩交土器が含まれている。それより新 しいクロスナ層には弥生式と考えられる土器が発見さ れ，その砂層直下の泥炭層の ${ }^{14} \mathrm{C}$ 年代は $2690 \pm 160 \mathrm{Y}$. B. P. (Gak.-816) である.もっとも新しいクロスナ層 はその下位の砂層内に弥生式末から土師器を含むので, それよりいくぶん新しいと考えられ，もっとも新しいク ロスナ層はそれより上位にわずかに暗色味をおびた暗黄 橙色砂層として挾まれている．これらのことにより田屋 砂層は完新世砂丘層であると言える.

玄海砂丘はこれまでの研究によると，ヴィふム風成砂 
層（もしくはレス状砂層）から構成されている砂丘で, 更新世の水期の環境下で風成堆積したものであるとされ ている新堀ら (1964).しかしながら，われわれのこれ までの調査によると, この砂丘は風成砂よりなる砂丘で はなく，扮とらく更新世の海水面の上昇注対応して堆積 した海成層よりなる段丘化した更新世の砂州であり，そ の上を薄く風成砂層によってお抢われているに過ぎな い. 風成砂層は更新世のものも一部にはあるが，大部分 は完新世の風成砂層である。完新世砂斥砂層に㣣をれる クロスナ層については各地の砂丘に打いて知られている が，玄海砂丘において 5 層を認めることが出来，これに より砂丘の形成期と安定期について諭ずることができる のである。

\section{IV. ま と め}

この小論では砂匠の形成に関する研究史を編み, 将来 研究すべき課題を指摘するとともに, 館林台地の埋積砂 丘, 三里浜·加越台地上の砂丘, 鹿島砂丘, 玄海砂丘の 研究を行なった，得られた成果はつぎのようである。

（1）館林台地の埋積砂丘 埋積砂丘法色の違いや挾 在口ーム層の多少によって上，下 2 つ砂層に分けられ るが，ともに細粒砂層よりなることから安定した環境下 で堆積したとみられる。

砂丘の形成時代は砂丘を叔打う口一ム層や砂丘砂層中 の軽石およびシルト質口ーム層との関係から, 中部口一 么層降灰の初期が，あるいは下部口一ム層降灰の未期で はないかと考えられる。

（2）三里浜・加越台地上の砂丘 三里浜砂丘の内陸 側砂丘は沖積世の海水準の相対的上昇時に形成されたも のである.加越台地上の凹地形では腐植層やローム層お よびその下位の粘土層などの産状から，口ーム層の一部 が四地形に堆積してグライ化作用を受けたり, 泥炭層の 形成と結びついて腐植が集積していることは，崖端付近 の海岸砂丘 (侵食砂丘) の形成される以前に, 凹地形で は停滞水の久られる環境下において腐植の集積が行なわ れたものとみられる。

（3）鹿島砂丘 鹿島砂丘は形成時代によって古期, 中期, 新期の各砂丘に分類される.ここでは繩文海進に よる砂州の形成後に，3 回の腐植層形成期を挾えで砂丘 が形成されている。

（4）玄海砂丘 玄海砂丘は風成砂よりなる砂丘では なく、路そらく更新世の海水面の上昇に対応して堆積し
た海成層よりなる段丘化した更新世の砂州であり，その 上を薄く風成砂層によってお拈われているに過ぎない， 風成砂層は更新世のものる一部にはあるが，大部分は完 新世の風成砂層である. また, 完新世砂丘砂層中に㣣を れるクロスナ層を 5 層認めることが出来, これによって 砂丘の形成期と安定期を明らかにすることができた。

\section{引用交献}

藤 則雄 (1966) 沖積世泥炭層と埋没林の層位学的研究 一北陸に打ける沖積統の研究 II. 地質学雑誌, 72, (1), $11 \sim 22$.

建設省・茨城県 (1964) 茨城県鹿島地区の地盤, 都市地 盤調查報告書, 6, $128 \mathrm{pp}$.

市瀬由自 (1962) 平野の形成と海岸砂丘. 資源研桑袁, (56-57), 51 61.

貝塚爽平（1958）関東平野の地形発達史. 地理学評論, 31, (2), 59 85.

川田三郎（1946）日本に於ける埋積砂丘. 資源研戬報, (10), $55 \sim 58$.

菊地隆男 (1968) 茨城県鹿島半島北部の地形発達史. 資 源研叠報, (70), 63〜 76.

三位秀夫 (1966) 沖積世に於ける海岸砂州の発達過程. 第四紀研究，5，(3〜4)，137〜148.

小笠原義勝（1946）荘内砂丘：資源研礐報，(10)，59～ 67.

小笠原義勝 (1948) 鳥取仯丘. 地学雑誌, 57, (1). 大西正己・近藤正史（1961）砂丘の生いたち.大明堂， $1 \sim 268$.

“新堀友行・鄉原保真・ 野村 哲 (1964) 北九州の玄海砂 丘の意義一そのレス状層について一。資源研 彙報, (63), 49 63.

多田交男 (1943) 鹿島灘砂丘一砂丘崩壤の 1 例一。地理 学評論, 19, (6), 262 263.

多田交男 (1946) 内陸砂丘の生成. 資源研䁷報, (10), $43 \sim 54$.

多田交男・嘉山英二 $(1947)$ 口-ム堆積前の地形。地理 学評論, $21,(2), 61 \sim 62$.

多田文男 (1948) 鹿島半島の侵食砂丘. 地理学評論, 21 $(9,10,11), 282 \sim 288$.

東北農政局計画部（1968）農業用大規模地下水調查 - 庄 内砂丘地区調查報告書. 6 .

戸谷 洋 (1960) 相模野北西部の地形に関するいくつか の問題. 辻村太郎生牛古稀記念地理学論交集, 107〜 118.

豊島吉則・赤木三郎 (1965) 鳥取砂丘の形成について. 鳥取大学学芸学部報告 (自然科学)，16，32４5.

和島誠一・松井 健 - 長谷川康雄 ·阔本 勇. 塚田 光 田中義昭 - 中村嘉男 - 小宮恒雄 - 黑部 隆 : 高橋健一 佐藤 孜 (1968) 関東平野における繩交海進の最高海 水準について，資源研檺報，(70)，108～129, 